Jakub Kozłowski*

ORCID: 0000-0003-2889-1426

Jagiellonian University

Anna Moskal ${ }^{* *}$

ORCID: 0000-0001-9070-069X

Jagiellonian University

DOI: $10.19195 / 1733-5779.29 .2$

\title{
The horizontal impact of the European Union Charter of Fundamental Rights in accordance with the sentencing guidelines of the European Court of Justice
}

\author{
JEL Classification: K3, K33
}

Keywords: horizontal, scope, Charter of Fundamental Rights, Bauer, EU

Słowa kluczowe: horyzontalny, zakres, Karta Praw Podstawowych Unii Europejskiej, Bauer, UE

Abstract: One of the biggest challenges of European law is balancing the relations between the Member States and the European Union. An especially interesting aspect of this issue is the horizontal impact of the European Union Charter of Fundamental Rights. The authors of the article will reconstruct the jurisprudence of the Court of Justice of the European Union, which precisely settles problems related to this issue. Various examples will be examined, ranging from the renowned judgment of the Grand Chamber of the Court in Case C-617/10 Aklagaren v Hans Akerberg Fransson to the most recent judgment of the Grand Chamber of the Court in Joined Cases C-569/16 and C-570/16 Stadt Wuppertal v Maria Elisabeth Bauer and Volker Willmeroth v Martin Broßonn. The authors will also evaluate the settled case law using a holistic perspective on the whole system of European law and its principles.

\footnotetext{
* Scientific Tutor (Opiekun naukowy) - prof. dr hab. Sławomir Dudzik

** Scientific Tutor (Opiekun naukowy) - prof. dr hab. Sławomir Dudzik
} 


\title{
Horyzontalny skutek oddziaływania Karty Praw Podstawowych Unii Europejskiej w linii orzeczniczej Trybunału Sprawiedliwości UE
}

\begin{abstract}
Abstrakt: Jednym z największych wyzwań prawa europejskiego jest uzyskanie balansu między systemami prawnymi poszczególnych państw członkowskich a systemem Unii Europejskiej. Zagadnieniem, które jawi się jako niezwykle interesujące w tym kontekście, jest horyzontalny skutek oddziaływania Karty Praw Podstawowych Unii Europejskiej. Autorzy artykułu dokonali rekonstrukcji linii orzeczniczej Trybunału Sprawiedliwości UE, która w sposób konsekwentny rozwija wykładnię tej problematyki — od legendarnego już wyroku wielkiej izby Trybunału w sprawie C-617/10 Áklagaren przeciwko Hansowi Åkerbergowi Franssonowi po najnowszy w badanym zakresie wyrok wielkiej izby Trybunału w sprawach połączonych C-569/16 i C-570/16 Stadt Wuppertal przeciwko Marii Elisabeth Bauer oraz Volker Willmeroth przeciwko Martinie Broßonn. Autorzy podjęli się także ewaluacji dotychczasowej linii orzeczniczej w sposób holistyczny, biorąc pod uwagę czynniki wynikające z całego systemu prawnego UE oraz jej zasad i wartości.
\end{abstract}

\section{Introduction}

The subject of analysis undertaken in this article is the process of developing the sentencing guidelines of the European Court of Justice (hereinafter: ECJ) in relation to the application of the EU Charter of Fundamental Rights (hereinafter: Charter, CFR), in particular, looking at its horizontal impact. The Charter is not only one of the main sources of primary EU law, but is also the largest set of fundamental rights which can be invoked by citizens of the Union. The scope and effects of the Charter are the subject of lively debates, featured in discourse in both academia and the media. The purpose of this article is to answer the question of whether the trend of the increasing use of the Charter, as adopted by the European Court of Justice, allows for the adoption of a thesis on the horizontal effect of the CFR. In order to answer the question asked, the authors of the article will examine the sentencing guidelines of the ECJ on the analysed issue, covering a number of judgments - from the-renowned judgment of the Grand Chamber of the Court in Case C-617/10 Aklagaren v Hans Akerberg Fransson ${ }^{1}$ to the most recent judgment of the Grand Chamber of the Court in Joined Cases C-569/16 and C-570/16 Stadt Wuppertal v Maria Elisabeth Bauer and Volker Willmeroth v Martin Broßonn. ${ }^{2}$ The article is divided into three main parts, which include the approximation of the Charter as a binding source of Union law, the scope of application of the CFR as recognised by the case law of the European Court of Justice and the question of allowing for horizontal impact of the Charter.

${ }^{1}$ Judgment of the Court (Grand Chamber) of 26 February 2013 in case C-617/10 Aklagaren $v$ Hans Akerberg Fransson, ECLI:EU:C:2013:105.

2 Judgment of the Court (Grand Chamber) of 6 November 2018 in Joined Cases C-569/16 and C-570/16 Stadt Wuppertal v Maria Elisabeth Bauer and Volker Willmeroth v Martina Broßonn, ECLI:EU:C:2018:871. 


\section{The EU Charter of Fundamental Rights as a binding source of Union law}

According to the established case law of the European Court of Justice and the content of Article 6 of the Treaty on European Union (hereinafter: TEU), the fundamental rights of EU citizens are treated as general principles of EU law. The fundamental catalogue of fundamental rights protected by EU law was enshrined in the Charter of Fundamental Rights of Nice in $2000 .^{3}$ However, it should be noted, that until the adoption of the Lisbon Treaty, the Charter was merely a political declaration which was not legally binding. ${ }^{4}$ Only Article 6(1) TEU, modified by the Lisbon Treaty in 2007, made it clear expressis verbis that the CFR has the same legal value as the Treaties and therefore is part of primary law of the European Union.

On 12 December 2007, a solemn proclamation of the Charter was made. This was necessary to approve the changes introduced in the Charter concerning, inter alia, the scope and interpretation of the rights and principles contained in the Charter, ${ }^{5}$ from 1 December 2009 onwards. In its updated version, the Charter became legally binding.

Most of the rights contained in the CFR were already in force for the addressees of the Charter, both under domestic laws and other EU or international legal acts. By confirming the rights contained in the Charter, it made them more visible. Among the sources of fundamental rights contained in the Charter are the European Convention for the Protection of Human Rights and Fundamental Freedoms (commonly referred to as the European Convention on Human Rights in academic and media discourse), the constitutional traditions of the Member States, international agreements relating to the protection of human rights, the provisions of the founding Treaties, and the rich case law of the European Court of Justice and the European Court of Human Rights. Over the last few years, the provisions contained in the CFR have increasingly been the subject of preliminary questions referred to the Court by the national courts of the Member States (in particular by the courts of Germany, Austria, Italy and the Netherlands). ${ }^{6}$ As M. Safijan rightly pointed out, fundamental rights are an extremely important part of the acquis communautaire of the ECJ and an essential component of European

${ }^{3}$ J. Barcz, A. Wyrozumska, M. Górka, Instytucje i prawo Unii Europejskiej. Podręcznik dla kierunków prawa, zarządzania i administracji, 5th ed., Warszawa 2017, p. 327.

4 J. Barcik, "Problematyka stosowania Karty Praw Podstawowych UE przez sądy polskie," Iustitia 3, 2015, p. 153.

5 J. Barcz, A. Wyrozumska, M. Górka, op. cit., p. 327.

${ }^{6}$ J. Łacny, "Stosowanie Karty Praw Podstawowych Unii Europejskiej w postępowaniach dotyczących funduszy Unii Europejskiej — wprowadzenie i wyrok Trybunału Sprawiedliwości z 3.07.2014 r., sprawy połączone C-129/13 i C-130/13, Kamino International Logistics BV i Datema Hellmann Worldwide Logistics BV przeciwko Staatssecretaris van Financien," Europejski Przeglad Sądowy 12, 2018, p. 49. 
identity. ${ }^{7}$ The provision which has been the subject of the most numerous analyses, both in case law and in doctrine, is undoubtedly Article 51 of the CFR, which regulates the scope of application of the Charter. ${ }^{8}$

\section{The scope of application of the EU Charter of Fundamental Rights}

Title VII of the CFR, which includes Articles 51 to 54, constitutes the principles for the application and interpretation of the Charter. Pursuant to Article 51(1) of the CFR

The provisions of this Charter are addressed to the institutions, bodies, offices and agencies of the Union with due regard for the principle of subsidiarity and to the Member States only when they are implementing Union law. They shall therefore respect the rights, observe the principles and promote their application in accordance with their respective powers and respecting the limits of the competences of the Union as conferred on it by the Treaties.

This law regulates the subjective and material scope of application of the Charter. Although it would appear from the wording of the provision that the personal scope of the provision is exhaustively defined, as the European Court of Justice observed in para. 87 of the judgment in joined cases C-569/16 and C-570/16 that

while Article 51(1) of the Charter provides that its provisions are addressed to the institutions, bodies, offices and agencies of the Union, in accordance with the principle of subsidiarity, and to the Member States only when they are implementing Union law, the said Article 51(1) does not address the question whether such persons may, where appropriate, be directly bound by certain provisions of the Charter and therefore cannot be interpreted as systematically excluding such a possibility.

In practice, apart from the issue of the subjective scope of Article 51 of the CFR, doubts also arose as to its material scope, in particular what exactly is covered by the expression "only to the extent that they apply [...] Union law," regarding the application of the Charter. The European Court of Justice has clarified in numerous preliminary rulings, referred to below, that this term means that the application of the Charter by the Member States is necessary when national legislation falls within the scope of Union law. ${ }^{9}$ In his comments on the CFR, ${ }^{10}$ A. Wróbel

${ }^{7}$ M. Safijan, "Fields of application of the Charter of Fundamental Rights and constitutional dialogues in the European Union," Distinguished Lecture, Centre for Judicial Cooperation, European University, Florence 2014.

8 See i.a. K. Lenaerts, "Exploring the limits of the EU Charter of fundamental rights," European Constitutional Law Review 3, 2012, pp. 375-403; N. Półtorak, "Zakres związania państw członkowskich Kartą Praw Podstawowych UE," Europejski Przeglad Sąowy 9, 2014, pp. 17-28; M. Szpunar, "Kilka uwag systematyzujących na temat zakresu zastosowania Karty Praw Podstawowych UE," Europejski Przeglad Sąowy 10, 2015, pp. 4-10.

9 That is the judgment of the Court for the first time in the judgment in the case C-617/10 Aklagaren v Hans Akerberg Fransson, ECLI:EU:C:2013:105.

10 A. Wróbel (ed.), Karta Praw Podstawowych Unii Europejskiej. Komentarz, Warszawa 2013, p. 1309. 
contemplated that Member States are bound by the fundamental rights set out in the Charter when they are directly bound by EU law to take the action in question (Wachauf formula ${ }^{11}$ ) and when the Union law requires Member States to comply with certain requirements during a derogation, understood as decisions to adopt derogations from the application of Union law (the ERT formula ${ }^{12}$ ).

It would be a truism to say that certain rulings of the ECJ can be seen as milestones in the development of European law. However, when discussing some of the Court's rulings, such a sentence is necessary. The role of the Akerberg Fransson ruling in the context of the issues at stake should be highlighted and made clear. The case concerned a Swedish entrepreneur to whom a double sanction for a tax offence could be applied (a tax sanction was first applied and a criminal sanction could also be applied). ${ }^{13}$ Such a situation is contrary to the principle of ne bis in idem, expressed in Article 50 of the CFR. The Court therefore had to rule on whether the issue in question fell within the material scope of application of Union law. Before referring to the solution adopted by the ECJ, it is worth pointing to the opinion of Advocate General Villalón, who proposed a solution to this problem that is now recognised in the literature. ${ }^{14}$ According to him, the measure of the presence of EU law in a given case would be the level "of sufficient intensity," tested each time and casuistically. We would agree with the position of N. Półtorak who rightly points out that the adoption of such an interpretation would be restrictive of the scope of the Charter, even if it were at the time of the judgment. ${ }^{15}$ Moreover, the use of such a broad and unclear clause would certainly not be considered as a universal solution for the future and would introduce far-reaching uncertainty for individuals and courts as to the extent of the jurisdiction of the Court. The Fransson ruling was made in a completely different spirit. It functionally extended the interpretation of the scope of application of the Charter to the present day, stating that if a given situation falls within the scope of application of EU law, then fundamental rights apply. It is worth noting the reaction of the German Federal Constitutional Court, which in its case law indicated that this tendency would not well perceived. ${ }^{16}$ In the present case, the application of EU law has consisted in introducing an act of EU law into the legal system of a Member State while leaving it a sufficient margin of discretion in the way it

11 "It concerns the situation 'in which Member States implement EU law, acting as the' executive branch of the Union"; see J. Barcik, op. cit., p. 155.

${ }^{12}$ Ibidem, p. 156.

13 Judgment of the Court (Grand Chamber) of 26 February 2013 in case C-617/10 Aklagaren $v$ Hans Akerberg Fransson, ECLI:EU:C:2013:105.

14 Opinion of the Advocate General P. Cruz Villalon of 12 June 2012 in case C-617/10 Aklagaren $v$ Hans Akerberg Fransson, ECLI:EU:C:2012:340, point $27 \mathrm{ff}$.

${ }^{15}$ N. Półtorak, op. cit., p. 20.

16 Judgment of the FCC of 24 April 2013, 1 BvR 1215/07. See J. Barcz, A. Wyrozumska, M. Górka, op. cit., p. 351. 
is implemented. Are there any other options for including a given situation in the material scope of the CFR?

The case law of the European Court of Justice clearly indicates that there are also situations where EU law defines the action of a Member State in its entirety. This relationship between EU rules and those of the Member State is characteristic, inter alia, of the Melloni judgment. ${ }^{17}$ The Spanish Constitutional Court held that Article 53 of the Charter allows for the application of a higher standard than that provided for in the CFR. The ECJ expressed a different view when deciding on the case. The main circumstance highlighted in the judgment is that the action seeking protection of fundamental rights is based entirely on EU law. This implies the exclusion of any incompatible rule stemming from the law of a Member State. ${ }^{18}$ Naturally, for an outside observer, such a decision could appear to be detrimental to the rights of the individual. However, the Court was guided by one fundamental value that had to be strengthened at the time - the principle of the primacy of EU law. It works not in a selective catalogue, adapted to the circumstances, but always.

The third possibility of applying the CFR should also be mentioned. There are provisions in the Treaties to derogate from the general rules (derogation). Typically, a derogation is justified by certain specific considerations which a Member State must follow in order to, for example, protect certain values. These derogations should be treated narrowly in order to prevent Member States from unilaterally defining them in a way that is not under the control of the Union institutions. ${ }^{19}$ The European Court of Justice in the Sayn-Wittgenstein case referred on several occasions in its arguments to Article 20 of the CFR, which includes the principle of equality, as relevant in this case. In addition, the exercise of those powers by the State must respect the other rights and freedoms deriving from the Charter. ${ }^{20}$

After analysing the cases in which the Charter may have a real impact on the case law of the Court, the authors wish to move on to another aspect of the work, namely the attempt to reconstruct the case law on the horizontal effect of the CFR. The starting point for such considerations may certainly be the reflection of R. Grzeszczak and A. Szmigielski, according to whom it is necessary to search

17 Judgment of the Court (Grand Chamber) of 26 February 2013 in case C-260/89 Stefano Melloni v Ministerio Fiscal, ECLI:EU:C:2013:107.

${ }^{18}$ D. Kornobis-Romanowska, "Poszanowanie praw podstawowych w państwach członkowskich Unii Europejskiej. W stronę zapewnienia spójnego poziomu ochrony praw człowieka w Europie?," Przeglad Prawa i Administracji 100, 2015, p. 455.

19 Judgment of the Court (Second Chamber) of 22 December 2010 in case C-208/09 Ilonka Sayn-Wittgenstein przeciwko Landeshauptmann von Wien, ECLI:EU:C:2010:806; see also: C-36/02 Omega, ECLI:EU:C:2004:614, C-33/07 Jipa, OJ C 223, 30.8.2008, p. 11.

20 E. Skibińska, Prawo Unii Europejskiej - orzecznictwo, Warszawa 2014, p. 383. 
for an appropriate link allowing for the application of the Charter, ${ }^{21}$ as a result of the Court's failure to develop a certain permanent methodology for classifying (or not) given legal states as falling within the scope of EU law. It is only with the development of a proper line of jurisprudence, culminating in the judgment in joined cases C-569/16 and C-570/16, discussed in the further part of the study, that it is possible to anticipate its existence or not. In order to illustrate this trend, it is worth recalling the judgment in the Mangold case. ${ }^{22}$ It concerned a dispute between W. Mangold and R. Helm, regarding potentially resulting provisions discriminating on the grounds of age. The main issue that the Court had to face was whether the provisions of Council Directive 2000/78/EC could be applied in such a case, ${ }^{23}$ allowing for the use of discriminatory provisions in specific cases. However, the Court looked at the whole case more holistically, analysing other acts of European law in the context of the protection of individual rights, noting that Council Directive 1999/70/EC, which was crucial for the decision, was needed. ${ }^{24}$ This was treated as a kind of a link between the EU and national law, which is characterised above all by its character. ${ }^{25}$ This is necessary in order to protect a private operator through the principle of non-discrimination enshrined in the CFR. ${ }^{26}$ The same conclusion was reached five years later in the Kücükdeveci case. ${ }^{27}$ Importantly, in both judgments, the Court made clear that the duty of the courts to ensure that the general principle of non-discrimination on grounds of age is fully effective. Of course, the role of the courts in the process of applying the Charter is a separate issue, but it should be stressed that it is an absolutely essential element of this process, perhaps the most important one from an individual's perspective, given its strictly functional nature.

In order to outline recent case law trends and to show that the Court has gone one step further on certain issues related to the application of the CFR, two judgments

21 R. Grzeszczak, A. Szmigielski, "Sądowe stosowanie Karty Praw Podstawowych UE w odniesieniu do państw członkowskich — refleksje na podstawie orzecznictwa Trybunału Sprawiedliwości i praktyki sądów krajowych," Europejski Przegląd Sądowy 10, 2015, p. 14.

22 Judgment of the Court (Grand Chamber) of 22 November 2005 in case C 144/04 Werner Mangold v Rüdiger Helm, ECLI:EU:C:2005:709.

23 Council Directive 2000/78/EC of 27 November 2000 establishing a general framework for equal treatment in employment and occupation, Official Journal L 303, 2/12/2000, P. 0016-0022.

24 Council Directive 1999/70/EC of 28 June 1999 concerning the framework agreement on fixed-term work concluded by ETUC, UNICE and CEEP, Official Journal L 175, 10/07/1999, P. 0043-0048.

25 Point 75 of judgment in case C-144/04.

26 Article 21 of Charter of Fundamental Rights of the European Union: „Any discrimination based on any ground such as sex, race, colour, ethnic or social origin, genetic features, language, religion or belief, political or any other opinion, membership of a national minority, property, birth, disability, age or sexual orientation shall be prohibited."

27 Judgment of the Court (Grand Chamber) of 19 January 2010 in case C 555/07 Seda Kücükdeveci $v$ Swedex GmbH \& Co. KG, ECLI:EU:C:2010:21. 
should be recalled: Association de médiation sociale ${ }^{28}$ and Egenberger. ${ }^{29}$ In the first, the Court, after having consolidated and recalled the case law relating to the absence of a horizontal direct effect of the directives, had to confront a situation in which an individual would be deprived of the protection afforded by the Charter due to the absence of a link between European Union law and its application in a Member State. In the context of that specific procedure, it did not allow direct application of the CFR between private individuals, since it considered that the provisions of the Charter in Title IV, entitled "Solidarity," were not suitable for direct invocation in disputes between private individuals. ${ }^{30}$ The most important part of the decision is the suggestion of a direct effect of horizontal nature of other provisions. This results from the division of provisions into rules that can only produce indirect effect and rights, implied in relevant factual and legal states. Thus, using a metaphorical form, it can be concluded that the Association de médiation sociale judgment repealed certain doors which were subsequently opened. This trend was further developed in the Egenberger judgment, according to which a court of an EU Member State

must ensure that individuals, within the limits of their powers, the legal protection afforded to them under Articles 21 and 47 of the Charter of Fundamental Rights of the European Union and to ensure the full effectiveness of those provisions, if necessary by disapplying any conflicting provisions of national law. ${ }^{31}$

This decision further emphasized the role of certain provisions of the CFR, confirmed the division of the provisions of the Charter and had an impact on the protection of individual rights.

\section{The final allowing of the horizontal behaviour of the EU Charter of Fundamental Rights in the joined cases C-569/16 and C-570/16}

On 6 November 2018 The European Court of Justice, Grand Chamber delivered its landmark judgment in Joined Cases C-569/16 Stadt Wuppertal v Maria Elisabeth Bauer and C-570/16 Volker Willmeroth v Martin Broßonn. Both cases were pending before the German labour courts and concerned cash equivalents for the unused paid annual leave of the deceased husbands of the applicants Maria Elisabeth Bauer and Martina Brossonn. The difference between the two cases was the nature of the employer: Mr Bauer was employed by the German town of Wuppertal and Mr Brosson worked in a private company owned by Volker Willmeroth. Since the

28 Judgment of the Court (Grand Chamber) of 15 January 2014 in case C 176/12 Association de médiation sociale $v$ Union locale des syndicats CGT and Others, ECLI:EU:C:2014:2.

29 Judgment of the Court (Grand Chamber) of 17 April 2018 in case C 414/16 Vera Egenberger $v$ Evangelisches Werk für Diakonie und Entwicklung eV, ECLI:EU:C:2018:257.

30 Opinion of the Advocate General Yves Bot of 29 May 2018 in joined cases C-569/16 and C-570/16, ECLI:EU:C:2018:337, point 67.

${ }^{31}$ Point 75 of judgment in case C-414/16. 
two deceased workers had not used all their days of paid leave before their death, their wives, as the only legal successors, turned to the former employers of their spouses for an allowance in lieu of the days not taken. Both the City of Wuppertal and Volker Willmeroth refused to pay that allowance on the basis of German legislation which provides that the deceased's entitlement to leave expires upon death and the claim that for an allowance in lieu of paid untaken annual leave it cannot be included in the estate. After the refusal of the employers to comply with their claims, each widow brought an action for payment of these allowances before the German labour court. Both claims were granted in the first instance and the appeal brought forward by the employers was dismissed by the competent higher labour courts. As a result of the dismissal of their appeals, the defendants brought an appeal to the German Federal Labour Court against these judgments. That court decided to refer the European Court of Justice to interpret Article 7 of Directive 2003/88 32 and Article 31(2) of the CFR ${ }^{33}$ in this specific context.

Written opinion ${ }^{34}$ in the cases brought forward was introduced by the eminent French Advocate General Yves Bot. At the outset of his analysis of the legal situation of the case, the Advocate General advocated maintaining the position adopted in the Bollacke judgment, ${ }^{35}$ in which the European Court of Justice ruled, with reference to the same provisions of German law, that Article 7 of Directive 2003/88 must be interpreted as precluding national legislation and/or practice, which provides that the right to paid annual leave ceases to exist and that entitlement to an allowance in lieu of leave not taken does not arise where the employment relationship ceases as a result of the death of the worker. $\mathrm{He}$ then argued that that solution would also apply in the present case, since the European Court of Justice took account of the succession in the Bollacke case. ${ }^{36}$ The Advocate General additionally considered the question of the horizontal effect of directives, to a large extent relying on existing and established positions of the European Court of Justice. The last and the most extensive considerations were devoted to the possibility of the spontaneous application of the provisions

32 Directive 2003/88/EC of the European Parliament and of the Council of 4 November 2003 concerning certain aspects of the organisation of working time, Official Journal L 299, 18/11/2003 P. 0009-0019, Article 7: "1. Member States shall take the measures necessary to ensure that every worker is entitled to paid annual leave of at least four weeks in accordance with the conditions for entitlement to, and granting of, such leave laid down by national legislation and/or practice. 2. The minimum period of paid annual leave may not be replaced by an allowance in lieu, except where the employment relationship is terminated."

${ }^{33}$ Article 31.2 of CFR: "Every worker has the right to limitation of maximum working hours, to daily and weekly rest periods and to an annual period of paid leave."

34 Opinion of the Advocate General Yves Bot of 29 May 2018 in joined cases C-569/16 and C-570/16, ECLI:EU:C:2018:337.

35 Judgment of the Court (First Chamber) of 12 June 2014 in case C 118/13 Gülay Bollacke v K+ K Klaas \& Kock B.V. \& Co. KG, ECLI:EU:C:2014:1755.

${ }^{36}$ Point 33 of Opinion of the Advocate General. 
of para. 2 of the CFR both vertically and horizontally. From the very beginning of his reflections, the Advocate General made his position clear by putting forward the following thesis:

In my opinion, Article 31(2) of the Charter has the characteristics required for it to be invoked directly in a dispute between private parties in order to exclude the application of national provisions which would have the effect of depriving a worker of his right to paid annual leave. ${ }^{37}$

When setting out his view, Mr Bot noted that the right to paid annual leave constitutes a principle of EU social law of particular importance, which gives the European Court of Justice the opportunity to categorise that right also as a fundamental social right in the full sense of the word, which, in the Ombudsman's view, would include the possibility of judicial redress in disputes between private individuals. Furthermore, the judgment of the Association de médiation sociale was examined in depth, ${ }^{38}$ in which the ECJ held that it was potentially permissible to rely on the provisions of the Charter in horizontal disputes. Therefore, in the opinion of the Ombudsman

finally, the obstacle that Article 51(1) of the Charter could constitute to the possibility of invoking the Charter directly in disputes between individuals should be definitively removed. Although this Article provides that the Charter's provisions "apply to the institutions, bodies, offices and agencies of the Union [...] and to the Member States only when they are implementing Union law," it does not explicitly exclude any effect of the Charter on relations between private individuals. ${ }^{39}$

According to the French lawyer, Article 31(2) of the CFR has the characteristics necessary for it to be invoked directly in a dispute between private individuals with a view to possibly precluding the application of conflicting provisions of national law. Those features are deemed to constitute the mandatory nature of the law and its self-enforceability, understood as the absence of any need for further legislation in order for the fundamental right recognised by the Charter to be effective $^{40}$. Yves Bot's opinion concluded with a bold and, in the authors' view, legitimate suggestion that the Court

should abandon the excessively restrictive approach to Article 31(2) of the Charter, adopting a balanced case-law position according to which, while not all the provisions of the Charter which uphold fundamental social rights have the characteristics necessary to recognise their horizontal direct effect, they must be recognised in the case of provisions which are mandatory and self-enforcing. In

${ }^{37}$ Point 53 of Opinion of the Advocate General.

38 Judgment of the Court (Grand Chamber) of 15 January 2014 in case C 176/12 Association de médiation sociale v Union locale des syndicats CGT and Others, ECLI:EU:C:2014:2.

${ }^{39}$ Point 78 of Opinion of the Advocate General.

${ }^{40}$ Points 80-82 of Opinion of the Advocate General. In the footnote to the features given, the Advocate General pointed out that similar reflections were presented by the current President of the C.K. Lenaerts in his work: "L'invocabilité du principe de non-discrimination entre particuliers," [in:] Le droit du travail au XXIe siècle, Liber Amicorum Claude Wantiez, Larcier, Bruxelles 2015, pp. 89-105. 
short, these cases provide the Court with an opportunity to ensure that the recognition of fundamental social rights is not left in the sphere of "wishful thinking." 41

The European Court of Justice accepted the arguments and suggestions set out in the Opinion of the Advocate General. The ECJ not only confirmed that the death of a staff member does not result in the expiry of his right to paid annual leave, but also argued in detail why the heirs of a deceased staff member may claim an allowance in lieu of paid annual leave not taken by them. Moreover, in the Bauer judgment, the Court decided to definitively allow the possibility of relying on the horizontal direct effect of Article 31(2) of the CFR. Considering the substance of the problem of the scope of the provision in question, the Court held that Article 31(2) of the CFR is sufficient to confer on employees a right which they may invoke in a dispute with their employer in a situation which is covered by the EU law and, as a result, subject to the scope of application of the Charter. As the European Court of Justice explained, the right to paid annual leave granted to all workers by Article $31(2)$ of the Charter is thus both mandatory and unconditional, and therefore does not require any further detail in the provisions of the European Union law or national law. ${ }^{42}$ The Court followed the sentencing guidelines taken in its recent judgments in Egenberger and IR by stating that Article 31(2) of the CFR (and presumably other articles having the same characteristics) is in itself sufficient to provide redress for individuals in private disputes. The direct consequence of this assertion is therefore not only the right to paid annual leave, but also a corresponding obligation on all employers to comply with it, including private ones. ${ }^{43}$

The authors of this article believe that the judgment of the Grand Chamber of the European Court of Justice in the Bauer and Broßonn cases could boldly award a milestone in the case law on the application of the Charter for several reasons. Firstly, the judgment confirms the constitutional status of the fundamental social rights enshrined in the Charter. Secondly, the judgment undoubtedly falls within the line of cases concerning the interpretation of Article 51 of the CFR presented in the third paragraph of the article. Thirdly, the judgment clearly makes it possible to attribute a horizontal direct effect to those provisions of the Charter which are mandatory and self-enforcing. According to the authors of this article, the Bauer and Broßonn judgments can be seen as a clipboard that consistently closes the Court's jurisprudence giving horizontal direct effect to certain provisions of the Charter and ultimately develops all the ambiguities and undefined interpretations that could have been found in the Mangold, Kücükdeveci, Association de Médiation Sociale and Egenberger cases.

\footnotetext{
${ }^{41}$ Point 95 of Opinion of the Advocate General.

42 Point 75 of judgment in joined cases C-414/16.C-569/16 and C-570/16.

43 Point 88-90 of judgment in joined cases C-414/16.C-569/16 and C-570/16.
} 


\section{Conclusions}

The judicature cited by the authors follows a linear and relatively coherent route, which was clamped together by the judgment in Joined Cases C-569/16 Stadt Wuppertal v Maria Elisabeth Bauer, and C-570/16 Volker Willmeroth v Martin Broßonn. In the opinion of the authors of this work, the European Court of Justice's extension of the direct application of the Charter's provisions, as adopted by the European Court of Justice, should be clearly assessed as positive. This assessment is supported in particular by the reinforced protection of individuals' rights. It should be stressed, however, that the analysed jurisprudence of the European Court of Justice has not yet been fully "closed" and comprehensively shaped. The question of classification of the provisions of the CFR on those which have a horizontal direct effect and those which can be invoked by individuals only in a dispute with the State requires further analysis. This issue will undoubtedly be the subject of further consideration by the ECJ in the future. The European Court of Justice may in subsequent relevant disputes modify the criteria adopted in Joined Cases C-569/16 and C-570/16 for adopting the horizontal effect of a provision by, for example, extending them to new conditions. The authors point out that the current uncertainty about the nature of the impact of certain provisions of the Charter may in practice give rise to complications resulting from a certain legal uncertainty, and that the burden of responsibility for the proper application of the Charter's provisions will also rest with private parties.

\section{References}

\section{Primary sources}

Judgment of the Court (Grand Chamber) of 22 November 2005 in case C-144/04 Werner Mangold $v$ Rüdiger Helm, ECLI:EU:C:2005:709.

Judgment of the Court (Grand Chamber) of 19 January 2010 in case C-555/07 Seda Kücükdeveci $v$ Swedex GmbH \& Co. KG, ECLI:EU:C:2010:21.

Judgment of the Court (Second Chamber) of 22 December 2010 in case C-208/09 Ilonka Sayn-Wittgenstein przeciwko Landeshauptmann von Wien, ECLI:EU:C:2010:806.

Judgment of the Court (Grand Chamber) of 26 February 2013 in case C-617/10 Aklagaren v Hans Akerberg Fransson, ECLI:EU:C:2013:105.

Judgment of the Court (Grand Chamber) of 26 February 2013 in case C-260/89 Stefano Melloni v Ministerio Fiscal, ECLI:EU:C:2013:107.

Judgment of the Court (Grand Chamber) of 15 January 2014 in case C-176/12 Association de médiation sociale $v$ Union locale des syndicats CGT and Others, ECLI:EU:C:2014:2.

Judgment of the Court (First Chamber) of 12 June 2014 in case C-118/13 Gülay Bollacke $v$ K $+K$ Klaas \& Kock B.V. \& Co. KG, ECLI:EU:C:2014:1755.

Judgment of the Court (Grand Chamber) of 17 April 2018 in case C-414/16 Vera Egenberger $v$ Evangelisches Werk für Diakonie und Entwicklung eV, ECLI:EU:C:2018:257.

Judgment of the Court (Grand Chamber) of 6 November 2018 in Joined Cases C-569/16 and C-570/16 Stadt Wuppertal v Maria Elisabeth Bauer and Volker Willmeroth v Martina Broßonn, ECLI:EU:C:2018:871. 
Judgment of the FCC of 24 April 2013, 1 BvR 1215/07.

Opinion of the Advocate General Y. Bot of 29 May 2018 in joined cases C-569/16 and C-570/16, ECLI:EU:C:2018:337.

Opinion of the Advocate General P. Cruz Villalon of 12 June 2012 in case C-617/10 Aklagaren v Hans Akerberg Fransson, ECLI:EU:C:2012:340.

\section{Secondary sources}

Barcz J., Wyrozumska A., Górka M., Instytucje i prawo Unii Europejskiej. Podręcznik dla kierunków prawa, zarzadzania i administracji, 5th ed., Warszawa 2017.

Barcik J., "Problematyka stosowania Karty Praw Podstawowych UE przez sądy polskie," Iustitia 3, 2015.

Biernat S., "Zasada pierwszeństwa prawa unijnego po traktacie z Lizbony," Gdańskie Studia Prawnicze 25, 2011.

Chalmers D., Hadjiemmanuil C., Monti G., Tomknins A., European Union Law: Text and materials, Cambridge 2006.

Le droit du travail au XXIe siècle, Liber Amicorum Claude Wantiez, Larcier, Bruxelles 2015.

Frantziou E., The Horizontal Effect of Fundamental Rights in the European Union: A Constitutional Analysis, Oxford 2019.

Grzeszczak R., Szmigielski A., "Sądowe stosowanie Karty Praw Podstawowych UE w odniesieniu do państw członkowskich - refleksje na podstawie orzecznictwa Trybunału Sprawiedliwości i praktyki sądów krajowych,” Europejski Przegląd Sądowy 10, 2015.

Jasiński F., Karta Praw Podstawowych Unii Europejskiej, Warszawa 2003.

Kornobis-Romanowska D., "Poszanowanie praw podstawowych w państwach członkowskich Unii Europejskiej. W stronę zapewnienia spójnego poziomu ochrony praw człowieka w Europie?," Przeglad Prawa i Administracji 100, 2015.

Kożuch M., "Karta Praw Podstawowych UE — samoistne źródło prawa czy zbiór zasad interpretacyjnych?," Europejski Przeglad Sąowy 10, 2015.

Leczykiewicz D., "Horizontal application of the Charter of Fundamental Rights," European Law Review 479, Oxford Legal Studies Research Paper No. 90/2013, https://ssrn.com/abstract=2328175.

Lenaerts K., "Exploring the limits of the EU Charter of fundamental rights," European Constitutional Law Review 3, 2012.

Lenaerts K., "Trybunał Sprawiedliwości Unii Europejskiej a ochrona praw podstawowych," Europejski Przeglad Sadowy 1, 2013.

Łacny J., "Stosowanie Karty Praw Podstawowych Unii Europejskiej w postępowaniach dotyczących funduszy Unii Europejskiej — wprowadzenie i wyrok Trybunału Sprawiedliwości z 3.07.2014 r., sprawy połączone C-129/13 i C-130/13, Kamino International Logistics BV i Datema Hellmann Worldwide Logistics BV przeciwko Staatssecretaris van Financien," Europejski Przeglad Sadowy 12, 2018.

Półtorak N., "Zakres związania państw członkowskich Kartą Praw Podstawowych Unii Europejskiej," Europejski Przeglad Sąowy 9, 2014.

Safijan M., "Fields of application of the Charter of Fundamental Rights and constitutional dialogues in the European Union," Distinguished Lecture, Centre for Judicial Cooperation, European University, Florence 2014.

Safjan M., "O różnych metodach oddziaływania horyzontalnego praw podstawowych na prawo prywatne," Państwo i Prawo 2, 2014.

Schiek D., "ECJ fundamental rights jurisprudence between member states' preorogatives and citizens' autonomy," [in:] The European Court of Justice and the Autonomy of the Member States, red. H.W. Micklitz, B. de Witte, Oxford 2011.

Skibińska E., Prawo Unii Europejskiej - orzecznictwo, Warszawa 2014. 
Szpunar M., "Kilka uwag systematyzujących na temat zakresu zastosowania Karty Praw Podstawowych UE," Europejski Przeglad Sadowy 10, 2015.

Tridimas T., The General Principles of EU Law, Oxford 2006.

Weatherill S., "The constitutional competence of the EU to deliver social justice," European Review of Contract Law 2, 2006.

Wróbel A. (ed.), Karta Praw Podstawowych Unii Europejskiej. Komentarz, Warszawa 2013. 